\title{
The Relationship between the Capsular and Cell Wall Polysaccharides of Strains of Lactobacillus casei var. rhamnosus
}

\author{
BY K. W. KNOX AND ELIZABETH A. HALL \\ Institute of Dental Research, United Dental Hospital, \\ Sydney, New South Wales, Australia
}

(Received 31 August 1964)

\begin{abstract}
SUMMARY
The polysaccharide components of an encapsulated and a non-encapsulated strain of Lactobacillus casei var. rhamnosus were compared. The main capsular component was a polysaccharide consisting of rhamnose, glucose and galactose. This polysaccharide resembles, chemically and serologically, one of the two polysaccharide components normally found in the cell wall of $L$. case $i$ var. rhamnosus. Since the cell wall of the encapsulated strain lacks the rhamnose-containing polysaccharide it seems likely that the capsule represents polysaccharide which has failed to become attached to the cell wall mucopeptide.
\end{abstract}

\section{INTRODUCTION}

The studies of Hammond (1961) and Sims (1964) have shown that some strains of Lactobacillus casei produce a capsule. Hammond (1961) isolated the capsular material and concluded that it contained approximately equimolar proportions of glucose and rhamnose. Subsequent reports (Hammond \& Williams, 1964 $a, b$ ) have detailed further aspects of investigations on the encapsulated strain. The strain studied by Sims was defined as $L$. casei var. rhamnosus on the basis of physiological and serological tests. Previous studies (Knox, 1963; Glastonbury \& Knox, 1963) have shown that the cell wall of $L$. casei var. rhamnosus contains rhamnose, glucose and galactose in addition to hexosamine and amino acids; furthermore, two serologically distinct polysaccharides are present, one containing rhamnose, glucose and galactose, and the other containing glucose, galactose and hexosamine. In the present work capsule and cell-wall preparations have been made from the strain isolated by Sims (1964), and their properties compared with those of cell-wall products previously (Knox, 1963) obtained from non-encapsulated strains of $L$. casei var. rhamnosus.

\section{METHODS}

Organisms. The encapsulated strain of Lactobacillus casei var. rhamnosus isolated by Sims (1964) was obtained from the National Collection of Type Cultures, Colindale, London, designated NCTC 10302. The other strains were those used in earlier studies (Knox, 1963) and were designated $L$. helveticus (L. casei var. rhamnosus) NCTC 6375, L. casei (var. casei) NIRD R094 and $L$. casei (var. casei) NIRD H 831 .

Serology. Antisera to strains NCTC 6375, NIRD R094 and NIRD H 831 were prepared as described previously (Knox, 1963). Strain NIRD H 831 belongs to sero- 
logical group B and strains NCTC 6375 and NIRD R094 to group C (Sharpe, 1955; Sharpe \& Wheater, 1957). The extent of cross-reaction between the antisera and extracts from strain NCTC 10302 were determined by qualitative and quantitative precipitin reactions (Knox, 1963; Glastonbury \& Knox, 1963).

Components of cell wall from Lactobacillus casei var. rhamnosus, strain NCTC 6375. Cell wall from strain NCTC 6375 was prepared as described previously (Knox, 1963). Soluble cell wall components were obtained by incubating cell wall with a preparation of Streptomyces muralytic enzyme; the rhamnose-containing polysaccharide is the major component of the product designated Fraction I (Knox, 1963).

A preparation of Fraction I was hydrolysed for $3 \mathrm{hr}$ at $100^{\circ}$ in $0 \cdot 1 \mathrm{~N}-\mathrm{H}_{2} \mathrm{SO}_{4}$. Oligosaccharide fractions were obtained by elution of the material from a charcoal + Celite column. Fractions eluted with 7.5, 15 and $25 \%(v / v)$ ethanol in water contained mixtures of oligosaccharides which were not further resolved. The component sugars in each case were rhamnose, glucose and galactose; rhamnose was the major component (Knox, unpublished observations). For serological studies the carbohydrate content of each fraction has been expressed as the sum of the molar amounts of each of the component sugars.

Analysis of preparations. The component sugars were detected by chromatography of acid hydrolysates. Methods for the determination of nitrogen and the component sugars were as described previously (Knox \& Brandsen, 1962).

\section{RESULTS}

Preparation of capsular material and cell wall from Lactobacillus casei var. rhamnosus strain NoTC 10302

The encapsulated organism NCTC 10302 was grown under the conditions described by Sims (1964). The culture fluid (500 ml.) was centrifuged at $19,000 \mathrm{~g}$ for $15 \mathrm{~min}$. and the organisms washed twice with $0.9 \%(w / v) ~ \mathrm{NaCl}$. The organisms were suspended in $250 \mathrm{ml}$. of $2.5 \%(\mathrm{w} / \mathrm{v}) \mathrm{NaCl}$ and shaken vigorously for $2 \mathrm{hr}$ at room temperature in a Dynamax Flask Shaker (Ainsworth Consolidated Industries, Sydney). The suspension was then centrifuged at $35,000 \mathrm{~g}$ for $20 \mathrm{~min}$.; the viscous supernatant fluid was removed and dialysed against frequent changes of distilled water. The extraction of the organisms was subsequently repeated for one $2 \mathrm{hr}$ period and two $5 \mathrm{hr}$ periods. After the final extraction, the organisms were washed twice with $2.5 \%(\mathrm{w} / \mathrm{v}) \mathrm{NaCl}$, and cell wall prepared by the method previously described (Knox, 1963). The cell wall and the extracts of capsular material were dried from the frozen state. The yield of cell wall was $65 \mathrm{mg}$; t the total yield of capsular material was $249 \mathrm{mg}$., made up as follows : first extract, $105 \mathrm{mg}$.; second extract, $103 \mathrm{mg}$.; third extract, $30 \mathrm{mg}$.; fourth extract, $11 \mathrm{mg}$.

The capsular material was further purified by precipitation with $\left(\mathrm{NH}_{4}\right)_{2} \mathrm{SO}_{4}$. A small amount of material was precipitated on adding an equal volume of saturated $\left(\mathrm{NH}_{4}\right)_{2} \mathrm{SO}_{4}$ at room temperature. After removing the precipitate by centrifuging, the $\left(\mathrm{NH}_{4}\right)_{2} \mathrm{SO}_{4}$ concentration of the supernatant fluid was increased to $55 \%$ saturation. A flocculent precipitate which formed on standing was dissolved in water, dialysed and dried from the frozen state. Solutions ( $0.5 \%)$ of the material were very viscous.

Strain NCTC 6375 was grown in the medium previously used when preparing cell wall (Knox, 1963), and also in the medium used by Sims (1964). Suspensions of 
washed organisms were shaken for $4 \mathrm{hr}$, centrifuged and the rhamnose content of the supernatant fluid and of the residue determined. In each case only $0.5 \%$ of the total rhamnose of the organisms was in the supernatant fluid. It may therefore be concluded that Lactobacillus helveticus (L. casei var. rhamnosus) strain NCTC 6375 does not form a capsule.

\section{Analysis of preparations from strain NoTO 10302}

The cell wall preparation, capsular material (second extract) and the purified product were analysed for component sugars and total nitrogen. The results are summarized in Table 1.

Table 1. Percentage composition of cell wall and capsule of Lactobacillus casei var. rhamnosus NCTC 10302

$\begin{array}{lccc}\text { Cell wall } & \overbrace{\begin{array}{c}\text { Second } \\ \text { extract } \\ (\%)\end{array}}^{\text {Capsule }} & \begin{array}{c}\text { Purified } \\ \text { product }\end{array} \\ \text { Rhamnose } & \overbrace{3} & \mathbf{3 9} & 49 \\ \text { Glucose } & 19 & 21 & 25 \\ \text { Galactose } & 14 & 17 & 27 \\ \text { Hexosamine } & \mathbf{2 3} & \mathbf{0} & \mathbf{0} \\ \text { Nitrogen } & \mathbf{6 . 5} & \mathbf{2 . 1} & \mathbf{1 . 3}\end{array}$

Serological examination of preparations

Acid-extracts of cell wall of Lactobacillus casei var. rhamnosus strain NCTC 10302 were examined for serological activity as described by Sharpe (1955). The extract gave a positive reaction with group $\mathbf{C}$ antiserum but not with group $\mathbf{B}$ antiserum. The serological properties of the purified capsular material were also studied; at a concentration of $10 \mu \mathrm{g} . / \mathrm{ml}$. the capsular material gave a strong reaction with antiserum to $L$. casei var. rhamnosus NCTC 6375 (serological group C) but did not react with antiserum to $L$. casei var. casei NIRD R094 (group C) and $L$. casei var. casei NIRD H 831 (group B).

The cross-reaction between the capsular material of strain NCTC 10302 and the antiserum to strain NCTC 6375 was examined by the quantitative precipitin method. Antiserum $(0.2 \mathrm{ml}$.) was mixed with increasing amounts of purified capsular material $\left(5-120 \mu \mathrm{g}\right.$.) in a total volume of $1.5 \mathrm{ml}$. After $1 \mathrm{hr}$ at $37^{\circ}$ and 3 days at $4^{\circ}$ the protein content of the precipitate was determined by the method of Heidelberger \& MacPherson (1943) by using Folin \& Ciocalteu's phenol reagent. The results are compared in Fig. 1 with those obtained for the homologous reaction between the antiserum and Fraction I from strain NCTC 6375.

As shown previously (Knox, 1963), the precipitin reaction between Fraction I from strain NCTC 6375 and homologous antiserum is inhibited by rhamnose and, more particularly, glucose. Preparations of oligosaccharides from Fraction I contained rhamnose, glucose and galactose (see Methods) and their ability to inhibit the precipitin reaction was examined. The oligosaccharide preparations were a mixture of products eluted from a charcoal + Celite column by increasing concentrations of 
ethanol in water, and the amount of carbohydrate added to the precipitin reaction could not, therefore, be expressed in terms of $\mu$ moles of oligosaccharide; instead, the amount added was expressed as the sum of the molar amounts of the component sugars. In Table 2 the inhibition of the precipitin reaction between capsular material of strain NCTC 10302 and antiserum to strain NCTC 6375 by oligosaccharides from Fraction I has been compared with the inhibition of the homologous reaction between Fraction I and antiserum to strain NCTC 6375.

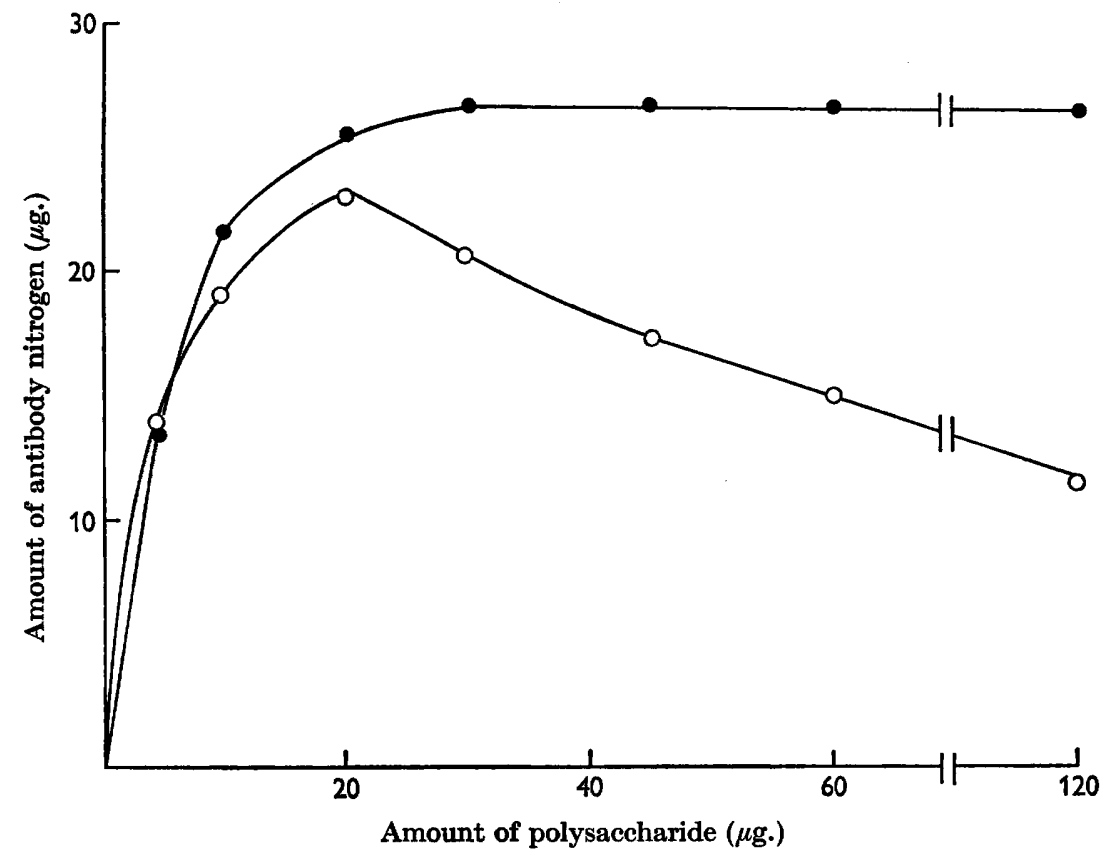

Fig. 1. Comparison of the precipitin reaction between capsular material from Lactobacillus casei var. rhamnosus strain NCTC 10302 (O) and Fraction I from L. casei var. rhamnosus strain NCTC $6375(O)$, with antiserum to NCTC 6375 .

Table 2. Comparison of the ability of oligosaccharide fractions from strain Lactobacillus casei var. rhamnosus NCTC 6375 to inhibit the precipitation of Fraction I from strain NCTC 6375, and capsular material from $L$. casei var. rhamnosus strain NCTC 10302 by antiserum to strain NCTC 6375

The antiserum (0.1 ml.) was mixed with the oligosaccharide preparations in a final volume of $0.8 \mathrm{ml}$, the solution of oligosaccharide containing approximately $5 \mu$ mole of component monosaccharides. After $1 \mathrm{hr}$ at $37^{\circ}, 0.2 \mathrm{ml}$. of solution containing $10 \mu \mathrm{g}$. of Fraction I or purified capsular material were added and the amount of precipitate formed on standing was estimated. The extent of inhibition was estimated by comparing the results with the amount of precipitate formed in the absence of oligosaccharides.

$\begin{array}{cccc}\begin{array}{c}\text { Carbohydrate } \\ \text { fraction (eluted } \\ \text { by \%, v/v, }\end{array} & \begin{array}{c}\text { Carbohydrate } \\ \text { content } \\ \text { (as } \mu \text { mole }\end{array} & \overbrace{\text { NCTC 6375 }}^{\text {\% Inhibition by }} & \begin{array}{c}\text { Capsular } \\ \text { material }\end{array} \\ \text { ethanol in water) } & \text { monosaccharide) } & \text { Fraction I } & 18 \\ 7 \cdot 5 & 5 \cdot 4 & 21 & 21 \\ 15 & 4 \cdot 7 & 30 & 19 \\ 25 & 4 \cdot 7 & 30 & \end{array}$




\section{DISCUSSION}

Sims (1964) defined the encapsulated strain of Lactobacillus casei var. rhamnosus (NCTC 10302) on the basis of physiological and serological tests. He was unable to show the presence of antibodies to the capsule nor would the encapsulated organisms absorb antibodies to a stock strain of $L$. casei var. rhamnosus. However, these studies were not extended to include the properties of soluble capsular material. Hammond \& Williams (1964a) studied the serological properties of the capsular material of a strain of $L$. case $i$ but were unable to show any cross-reaction between the soluble capsular material and antiserum to a 'non-encapsulated variant'.

Strains of Lactobacillus casei var. rhamnosus belong to serological group C, whereas strains of $L$. casei var. case $i$ belong to group B or C (Rogosa \& Sharpe, 1959). Strains of $L$. casei var. casei contain a cell wall polysaccharide in which glucose and galactose are the predominant sugars and are responsible for serological specificity (Knox, 1963; Knox \& Hall, 1965). Strains of L. casei var. rhamnosus contain an additional specific polysaccharide as a component of the wall, the predominant carbohydrate of this polysaccharide being rhamnose (Knox, 1963).

Analyses of cell wall preparations from a number of strains of group $\mathbf{C}$ organisms indicate that rhamnose is always a major component of the cell wall of Lactobacillus casei var. rhamnosus, whereas it is only a minor component of the wall of $L$. case $i$ var. casei (Glastonbury \& Knox, 1963). It would, therefore, have been expected that rhamnose would be a component of the cell wall of $L$. casei var. rhamnosus strain NCTC 10302; however, rhamnose is virtually absent from this, the amount of rhamnose in the wall preparation representing $2 \%$ of the amount in the capsular material. The carbohydrate components and serological properties of the wall are thus those expected for a strain of $L$. case $i$ var. casei, group C, or alternatively for an atypical strain of $L$. casei var. rhamnosus lacking the rhamnose-containing polysaccharide.

The carbohydrate analyses of the capsular polysaccharide indicate that this product is similar in composition to the specific rhamnose-containing polysaccharide previously found to be a component of the cell wall of Lactobacillus casei var. rhamnosus (Knox, 1963); in each case the molar ratio glucose:galactose:rhamnose approximates $1: 1: 2$, and hexosamine is absent. The results of serological studies also indicate a similarity between the capsular and cell wall polysaccharides, both reacting with antiserum to $L$. casei var. rhamnosus but not with antiserum to $L$. casei var. casei of group B or C. Further, oligosaccharide preparations from Fraction I of strain NCTC 6375 inhibit the precipitin reaction between the capsular material from strain NCTC 10302 and antiserum to strain NCTC 6375.

As shown in Fig. 1, differences in the reactivity of capsular and cell wall polysaccharides were noticeable when increasing amounts of the preparation were added to antiserum to strain NCTC 6375. With the capsular material, addition of increasing amounts did not lead to a diminution of precipitation while the cell wall product showed inhibition when twice the quantity required for maximum precipitation was used. These differences are probably due to differences in the molecular weight of the two products, as indicated by the marked differences in the viscosities of their solutions. Kabat \& Berg (1953) obtained similar results in their studies on the precipitin reaction between antiserum to dextrans and dextrans of 
various molecular weights. They concluded that the effect was almost certainly a function of the larger number of molecules per unit weight of the smaller molecular weight products.

The results of chemical and serological studies on the encapsulated strain of Lactobacillus casei var. rhamnosus (NCTC 10802) isolated by Sims (1964) show that the cell wall lacks the rhamnose-containing polysaccharide found in non-encapsulated strains, whereas the capsular layer contains a polysaccharide which is indistinguishable from the specific rhamnose-containing polysaccharide. This specific polysaccharide is normally joined to the cell wall mucopeptide by a covalent linkage (Knox, 1963; Hall \& Knox, unpublished observations) and strain NCTC 10302 may, therefore, lack the ability to complete the synthesis of cell wall by attaching the rhamnose-containing polysaccharide to the cell wall mucopeptide. The continued production of the polysaccharide then results in its being present as a capsular layer which is readily extracted from the cells.

This work was supported by a grant from the National Health and Medical Research Council of Australia.

\section{REFERENCES}

Glastonbury, J. \& Knox, K. W. (1963). The serological classification of varieties of Lactobacillus casei. J. gen. Microbiol. 31, 78.

HAMMOND, B. F. (1961). Isolation and characterization of a capsular polysaccharide from L. casei. Bact. Proc. p. 95.

Hammond, B. F. \& Winfams, N. B. (1964a). Serological properties of the capsular material of Lactobacillus casei. Nature, Lond. 202, 929.

Hammond, B. F. \& Wruliams, N. B. (1964 b). Studies on encapsulated lactobacilli. I. Utilization of capsular material by Lactobacillus casei. Arch. oral Biol. 9, 341.

Heidelberger, M. \& MacPherson, C. F. C. (1943). Quantitative microestimation of antibodies in the sera of man and other animals. Science, $97,405$.

KABAT, E. A. \& Berg, D. (1953). Dextran-an antigen in man. J. Immunol. 70, 514.

KNox, K. W. (1963). Isolation of group specific products from Lactobacillus casei and L. casei var. rhamnosus. J. gen. Microbiol. 31, 59.

Knox, K. W. \& Brandsen, J. (1962). The isolation of components from the cell wall of Lactobacillus casei. Biochem. J. 85, 15.

KNox, K. W. \& Hall, E. A. (1965). The isolation of oligosaccharides from the cell wall polysaccharide of Lactobacillus casei, serological group C. Biochem. J. (In the Press.)

Rogosa, M. \& Sharpe, M. E. (1959). An approach to the classification of lactobacilli. J. appl. Bact. 22, 829.

SharPE, M. E. (1955). Serological classification of lactobacilli. J. gen. Microbiol. 12, 107.

Sharpe, M. E. \& Wheater, D. M. (1957). Lactobacillus helveticus. J. gen. Microbiol. 16, 676.

Srms, W. (1964). A pathogenic lactobacillus. J. Path. Bact. 87, 99. 